Article

\title{
On Authoritarian Political Representation in Contemporary China
}

\author{
Demin Duan \\ School of Government, Peking University, 100871 Beijing, China; E-Mail: demin.duan@pku.edu.cn
}

Submitted: 27 March 2019 | Accepted: 24 May 2019 | Published: 24 September 2019

\begin{abstract}
Both in the Party Charter and in the State Constitution, the Chinese Communist Party claims to represent the Chinese people. Instead of treating this claim as mere rhetoric made by the party for propaganda purposes, this article demonstrates that it indicates a rather significant transition in the party's understanding of its relationship with the people. Particularly, roughly about two decades into the Open and Reform policy initiated under the leadership of Deng Xiaoping, the party made a strategic choice in imagining itself as the representative of the people instead of the revolutionary vanguard. This change in the language was very remarkable in the post-1949 Chinese history, in the sense that the party no longer considers itself as the facilitator of proletariat revolution, but as the authoritarian representative in the political community. If representation means "re-presentation", as in bringing something absent present, this appears to be what the party tries to do. By embodying the nation, the party tries to represent both the rich and the poor, acting as the arbiter of forever present discords and conflicts within the society. Clearly, this representation has nothing to do with what people usually call "democratic" representation. But considering that representation and democracy are conceptually rooted in very different sources, exploring "authoritarian representation" in contemporary China would enable us to better understand both China and democratic representation.
\end{abstract}

\section{Keywords}

authoritarian politics; authority; China; Chinese Communist Party; deliberation; democracy; representation

\section{Issue}

This article is part of the issue "Rethinking Representation: Representative Claims in Global Perspective", edited by Petra Guasti (Goethe University Frankfurt, Germany) and Brigitte Geissel (Goethe University Frankfurt, Germany).

(C) 2019 by the author; licensee Cogitatio (Lisbon, Portugal). This article is licensed under a Creative Commons Attribution 4.0 International License (CC BY).

\section{Introduction}

In today's China, the Chinese Communist Party (hereinafter abbreviated to "CCP" or "the Party") claims to represent the People. It also claims that it is mandated by history to represent the nation, in accordance with the tenets of justice, fairness, harmony, freedom, and so on. Usually, this claim is treated as mere rhetoric for propaganda purposes. But considering it from its historical background, it indicates a rather significant transition in the party's understanding of its relationship with the people. Particularly, roughly about two decades into the Open and Reform initiated under the leadership of Deng Xiaoping, the party made a strategic choice to imagine itself as the representative of the people instead of the revolutionary vanguard. This change in the language was very remarkable in the post-1949 Chinese history, in the sense that the party no longer considers itself as the facilitator of proletariat revolution, but as the authoritarian representative in the political community. If representation means "re-presentation," as in bringing something absent present, this appears to be what the party tries to do. By embodying the nation, the party tries to represent both the rich and the poor, acting as the arbiter of forever present discords and conflicts within the society. Clearly, this representation has nothing to do with what people usually call "democratic" representation. But representation and democracy are conceptually rooted in very different sources, only coming into alliance in modern times, as Hannah Pitkin and others have shown. By shedding light on representation in an "undemocratic" context, we could better understand regimes such as the contemporary Chinese Party-State and what makes representation "democratic". 


\section{The Representative Turn}

Usually, the most important turn in contemporary Chinese history can be traced to 1978 , when right after the disastrous Cultural Revolution, the Third Plenary Session of the 11th Central Committee of the CCP announced its Open and Reform policy. Under the leadership of Deng Xiaoping, the Party opened the country to the world and conducted many reforms-especially economic-within the country. The massive surge in economic development, the so-called "rise of China," and the drastic change in the society and people's lives in China are all direct results of this policy. So, it is a very crucial "turn" in every sense of the word. Actually, there is another turn, and one which is no less important. But perhaps, because it happened at a much less dramatic historical juncture, it is not even noticed as a turn. Only in the light of this second turn, however, can the true political significance of the Open and Reform policy, which has been mostly fathomed in economic terms, be properly understood. On 24 February 2000, on an inspection tour to Guangdong Province, the then Chinese president and General Secretary of the CCP Jiang Zemin stated the following:

A review of our Party's 70-plus-year history elicits an important conclusion: our Party earned the people's support during the historical periods of revolution, construction and reform because it always represented the requirements for developing China's advanced productive forces, the orientation of China's advanced culture and the fundamental interests of the overwhelming majority of the Chinese people. (Jiang, 2013, pp. 1-2, emphasis mine)

As it turned out, this is not a random "pep talk" spelled out on an occasional tour. It can be identified as the start of a well-designed ideological campaign that lasted for many years and arguably defined Jiang's presidency (Bo, 2004; Dickson, 2003; Jia, 2004; Kuhn, 2010, pp. 107-109; Patapan \& Wang, 2018; Song, 2005). Two years later, the "Three Represents" slogan was ratified by the CCP at the Sixteenth Party Congress and was incorporated into the revised Party Charter. Another two years later, in 2004, it was finally enshrined into the newly revised State Constitution and given an official title "The Important Thought of 'Three Represents'", next in line to Marxism, Leninism, Mao Zedong Thought, and Deng Xiaoping Theory. Although, Jiang's name is not mentioned here, it is undoubtedly one of his most recognized political legacies in China (Bo, 2004).

No serious China observer would doubt the importance of this "Three Represents" slogan. As many pointed out, "banners" such as the "Three Represents", "Scientific Outlook on Development" and the "China Dream" are extremely important, offering normative directions and policy initiatives for the nation (Kuhn, 2010, pp. 107-108; Patapan \& Wang, 2018). Particularly, under the cover of Party building and disciplining required by the idea of the "Three Represents", the phrase "the Party always represented" quickly turned into a normative requirement, whereby "it should always represent". It was thus made mandatory for (mostly local) Party officials to do what they could to promote the general interests of the People-largely understood in economic termsby way of attracting private investment, encouraging foreign trade, developing high technologies, etc. In comparison, the "Scientific Outlook on Development" promulgated by president Hu Jintao was largely seen as a response to the extensive "unscientific" style of economic growth in the preceding decades. Thus, referring to the state-society/public-private relationship in the Chinese case, Dickson comments in an article back in 2003 that the "Three Represents" slogan signifies the Party's willingness to allow its ties to the rest of society to weaken (Dickson, 2003, p. 12). Starting from similar ground, Jia Hepeng draws a rather contrasting conclusion by saying that the Party was "in fact, strengthening its orthodox ideology so as to increase its authority and legitimacy" in times of fast economic development and social change (Jia, 2004, p. 261). Similarly, Song opines that this campaign was just another old school ideology game played by the Party to "reconceptualise reality" in order to solidify its ruling position (Song, 2005, p. 32).

Important and interesting as these observations are, what they do not capture is that the new language adopted by the Party actually reflected a new reality in China. The crucial question to our analysis here is: Why the Party use the term "representative" instead of the much more commonly used one- "the vanguard" (xian feng)? To be sure, the term "vanguard" is still used today, in both the Party Charter and the State Constitution, denoting the party's "communist" nature. But ever since 2002 , it was put side by side with the term "represent" in the opening paragraph of the Party Charter, which now states the following:

The Communist Party of China is the vanguard for the Chinese working class, the Chinese people and the Chinese nation. It is the core of leadership for the cause of socialism with Chinese characteristics and represents the development trend of China's advanced productive forces, the orientation of China's advanced culture and the fundamental interests of the overwhelming majority of the Chinese people. (CCPS Editors, 2013, p. 363, emphasis mine)

These two sentences, emphasizing two apparently different elements- "vanguard" and "represent,"-actually summarize the Party's historical evolution. Since its inception, the CCP has revised its Party Charter at every plenary session of the Party Congress, thus, 19 versions of the Charter have been created so far. A pattern arises when we browse through all these versions (see CCPS Editors, 2013), especially the first sentences that declare the Party's structure and aim. The earlier back in time we 
go, the more the Party characterizes its nature and aim as "universal." From 1921 to 1943, the Party explains what it is up to by asserting its membership of the Communist International and its role as the vanguard of the "universal" class. However, in 1945, at the end of the SinoJapanese War and the beginning of the Second Chinese Civil War (1945-1949), it asserted that it was the vanguard of the "Chinese" working class, speaking for the interests of the Chinese Nation and People. After the Party won the civil war, the "national" character of the Party seemed to give way to a more universalistic orientation. The language in the Party Charter swung back to strong terms like "vanguard of the working class" and "radical revolution," which lasted until the end of the Cultural Revolution in late 1970s. In the 1982 version of the Party Charter, the Party started to present itself as one who "represents" the interests of all nations (or ethnic groups) in China, while still acting as the "vanguard of the working class." Then in 2002, as mentioned above, the "Three Represents" was promulgated and incorporated into the Party Charter, with a "representation" narrative seeming to overtake the narrative of the "vanguard".

In history, of course, the term "vanguard party" deals essentially with Vladimir Lenin's distinction between a party of reform and a vanguard party of revolution. Capitalism, as Lenin (1969) argued, predisposes the workers to the acceptance of socialism; but the proletariat, on its own or under reformist party leadership, can only achieve "trade-union consciousness." A new type of party is thus needed to imbue the working class with revolutionary consciousness, which led them to combat repressive economic political systems such as tsarism, and usher forth the transformation of society. In this regard, as Lenin says, "the role of vanguard fighter can be fulfilled only by a party that is guided by the most advanced theory" (Lenin, 1969, p. 26). In this sense, the vanguard party is both outside and inside the working class as well as both visible and invisible. That is, it lies outside the working class and is thus forcefully visible, since it has to bring consciousness to the working class and effectively bring about revolutions. But at the same time, it is also inside the working class and "invisible" in the sense that the party's aim is not really to rule society, but to let the people (or the working class) be aware of their own historical mission and be able to rule themselves. If this is the "classical" sense of political representation in the Leninist tradition, apparently, the CCP distanced itself from it by shifting from "vanguard" to "representation."

In this context, "representation" means very different things. We can say that a portrait represents the person portrayed, or an actor on stage in a Shakespearian play represents Hamlet. But it makes no sense to say that a portrait acts as the vanguard of the person portrayed, or that an actor is the vanguard of the role he/she plays. Hannah Pitkin gives a general definition to representation by saying that it literally means representation-"the making present in some sense of something which is nevertheless not present literally or in fact" (Pitkin, 1967, p. 9). But both "vanguard" and "representation" in the CCP's language seem to contain some of this definition. Jean-Jacques Rousseau was helpful in this regard when he charges that representation is by nature a "feudal" institution, distinct from the people's rule (Rousseau, 2002, pp. 211-212). In his understanding, political representation-in whatever forminevitably sets the representatives apart from the represented (the people), and places the former above the latter. Hence, his uncharitable comment that the English nation is only free "during the election of members of Parliament; as soon as they are elected, it is enslaved and counts for nothing" (Rousseau, 2002, p. 211). However idiosyncratic this Rousseauian definition may seem today, we believe it succinctly summarizes the practice of political representation as a form of ruling, a point that could easily be drowned out by people's equation of representation and democracy in today's language. Therefore, from this Rousseauian perspective, Leninist revolutionary vanguard would not be a form of representation because the intention of vanguard is not exactly to rule the society, but to transform it through revolution. Furthermore, we venture to say that the sense of representation contained in the "Three Represents" tilts towards this Rousseauian definition of political representation and is largely different from the vanguard idea.

The meaning of the CCP's turn from vanguard to representative becomes much clearer when we go back to the moment when the Party spelled out the "Three Represents." Around the year 2000, two decades into the Open and Reform era, the form and composition of society have changed rapidly. Before the 1980 s, society was governed and structured using Marxist egalitarian principles, and the People were generally poor. Although, there were inequalities among people during this time, especially between those in the city and the countryside, between those who worked for state-owned enterprises and those who did not, these can be identified as largely "bureaucratic" rather than class-based inequalities (Dillon, 2015). As popularly known, the Open and Reform policy propelled the country onto fast-track economic development. This may have been naturally good for the People, but it poses political challenges to the Party. For after two decades of growth, the workers and peasants, whom the Party is supposed to speak for, were seen at the bottom of the newly emerged social stratification, while cadres, quasi-cadres, and "capitalists," such as private business owners and entrepreneurs, are better off.

As a social phenomenon, this was heavily discussed by Chinese intellectuals at the time, leading to government censorship of some publications (Lu, 2002; Zheng, 2004). This social stratification was confirmed by Li Yi's research based on statistical data (Li, 2005). Obviously, this does not go well with the Party's image as a proletariat vanguard. The looming question to be asked is: Is the Party still a communist party or not? If it is, how are the working class and peasants now found at the bottom 
of the society? After the 1980s, Party theorists worked very hard to justify the course taken by the Party, mostly emphasizing the need to combine local Chinese realities and characteristics with Marxist theories and ideologies (Choi, 2011). It is no coincidence then, that around this time, the term "representation" emerged in the Party's updated self-portrait of its relationship with the Chinese People. By representing the People, the Party does not have to negate any social strata or class. Instead, it mediates their potentially conflicting interests, synthesizes them, and goes beyond them to the level of far-sighted, overarching "general interests." By presenting these general interests, the Party brings what is absent, present-a literal meaning of "representation".

Theoretically, of course, the Party could have switched back to vanguard mode at this historical juncture. But instead, it chose to reassert its authority without alienating the newly emergent "capitalistic" forces. Although, capitalistic forces are not specifically mentioned in the "Three Represents," it is clear from the language and corresponding policies that "capitalists" are no longer seen as the "enemy of the people" who should be eliminated here and now. In the light of this, after 2002, the CCP began to open its membership to those who had more commonly been considered as the people's enemy: mostly entrepreneurs and technical personnel (Renmin Ribao, 2003). In a speech given at the 80th anniversary of the Party, President Jiang declared that they would "join workers, farmers, intellectuals, cadres and PLA officers and men in an effort to build socialism with Chinese characteristics". Therefore, it became "necessary to accept those outstanding elements from other sectors of the society who have subscribed to the Party's Programme and the Constitution....and have met the requirements for the Party's membership through a long period of tests" (Jiang, 2013, p. 280). This attests to the above argument that the Party does want to be a representative that presents a unified image of the People. This is not to say that the Party has forsaken its communist (or vanguard) nature, indeed, this is far from the truth. Looking at it from both historical and theoretical perspectives, there has been a "representative turn" in contemporary China, one that is in a way even more significant than the turn made by the Open and Reform policy.

\section{Representation in the People's Congress}

In order to fully explicate the CCP's representation, there is need to further put it under a local comparative light by briefly mentioning the other form of "representation" in the Chinese political context, one that is more widely known and talked about, namely, representation in the People's Congresses. Indeed, members of these congresses-both the National People's Congress (hereinafter abbreviated as "NPC") and Local People's Congress-are called "representatives of the people" (ren min dai biao). As the Constitution and the law re- quire, they have to be elected by the People, and they do go through electoral processes. As members of legislative bodies, they are supposed to represent the views and interests of their constituents and review governmental reports, including their budget, law proposals, policy proposals, and so on. So, in the face of it, they are not so far away from what political representation looks like, for instance, in western democratic countries. But of course, the difference is that these elections are tightly controlled by Party-led authorities and the representatives are largely authorized to sit in congress by the Party instead of the electorate (Yuan, 2011).

However, it should be noted that, once in congress, some representatives could act defiantly against the Party authority and challenge its position on certain major issues, as Mr. Huang Shunxing did in 1992 when the NPC voted for the massive Three Gorges project proposal. The controversial project proposal was passed, but not without a historical record of both objecting and abstaining votes $(6.7 \%$ voting no, $25.2 \%$ abstaining, and $0.09 \%$ not voting). In a later interview, speaking on his motive for objecting, Mr. Huang said that, as both a representative of the People and a member of the human community, his absolute responsibility was to speak the truth as he saw it (Huang, 2013). It could be said that, in challenging the Party's position, Mr. Huang formed a direct representational relationship with the people as a whole, not primarily by referring to the electoral process that supposedly put him in congress, but by referring to some "high values". The Constitution of China, for instance, specifically states that the NPC is the highest state organ and has the right and power to elect the president and oversee the government. This alone should give some members of the NPC enough sense of honor and duty, despite the NPC's de facto status in the political system.

On the other hand, there has been much debate recently on the emergent ability of the People's Congresses today to restrain the government's power, to the extent that they may inch towards a certain kind of "check and balance" dynamism (Almén, 2013; Kamo \& Takeuchi, 2013; Manion, 2015; Truex, 2016). However, nobody could yet deny the fact that congresses are not really independent from the Party. To put the Party-Congress relationship in context, in the 1980s, Deng Xiaoping directed that the Party should no longer substitute itself for the state-a typical organ of which is the People's Congress-but function behind it, providing fundamental principles and guidelines (Deng, 1994). The purpose of this, however, was not exactly to put a check on the Party, but to consolidate the Party's power on a largely different basis-which is summarized in this article as "the representative turn." From our perspective, the People's Congress actually participates in the Party's representation of the People, rather than forming an institutional check on it. On the one hand, it is difficult today to imagine that any law or public policy proposal may enter the NPC, let alone be passed, without the Party's initial consent. In other words, the real ulti- 
mate representative claims on the People's general interests have to be made by the Party. But on the other hand, it also seems imperative that these claims be formally passed by the NPC and presented as the voice of the People. This mere process, guaranteed by Deng's Principle of Party-State separation, functions to moderate the Party's power, forcing it to seriously consider the kinds of proposal it puts through the NPC. This is exactly why the composition of NPC representatives is so visibly descriptive of the components of Chinese societyman, woman, workers, farmers, soldiers, cadres, different ethnicities, different provinces, Party members and non-Party members, etc. (Yi, 2010, pp. 46-47). When the NPC annually convenes, the representatives usually put on outfits that directly depict their supposed identity. By so doing, the Party solely represents the People, making exclusive claims on their general interests, with the NPC forming an integral part of this representation.

\section{Representation without Elections}

The above analyses have been made with the assumption that political representation is conceptually distinct from democratic politics, and hence, could be meaningfully aligned with authoritarian regimes. This disentanglement of political representation and democracy, however, is hardly something new. In the western tradition, from Jean-Jacques Rousseau's early critique of representation (Rousseau, 2002, pp. 221-222), to contemporary reflections on representation and democracy such as in Hannah Pitkin (2004), many scholars tend to distinguish the two, while defending democracy. However, the thriving of representative democracy in modern times significantly contributes to the confounding of the two concepts. David Poltke, for instance, states that representation is the same as democracy in an article titled "Representation is Democracy" (1997). In her article "Representation and Democracy: Uneasy Alliance", Pitkin characterizes the uneasy relationship between the two:

Like most people even today, I more or less equated democracy with representation, or at least with representative government. It seemed axiomatic that under modern conditions only representation can make democracy possible. That assumption is not exactly false, but it is profoundly misleading, in ways that remain hidden if one treats it as an axiom and asks only technical rather than fundamental theoretical questions. (Pitkin, 2004, p. 336)

Against this background, and given the global domination of western concepts in political theory discussion today, perhaps, it is worthwhile to mention Michael Saward's contribution in order to clarify where we stand theoretically in our discussion of political representation in China.

Saward (2006) criticizes traditional understanding of representation in representative democracy for largely taking the represented as an unproblematic given, while he tries to refocus attention on how representatives shape or construct the represented by making subjective claims. Both logically and factually, representative claims could exist outside what people usually understand as democratic politics. He notably cites the U2 singer and political activist Bono, who stated: "I represent a lot of people [in Africa] who have no voice at all.... They haven't asked me to represent them. It's cheeky, but I hope they're glad I do" (Saward, 2009, p. 1). He did not move to apply this approach to authoritarian politics, but it appears to have the potential. However, the problem with this approach is how to reconcile the subjectivity of representative claims with an inevitable demand for "objective" meanings. While representative claims are certainly subjective in nature, not all of them are accepted as truthful in a given society at a certain time.

Saward employs culture to explain this problem. He argues that culture sets limits or parameters as to the type of "claims" - or subject-object links-that can plausibly be made in any given context (Saward, 2006, p. 311). But he also claims that cultural codes themselves could somehow be constructed. If that is true, then how could they function as a stabilizing and restraining force for subjective representative claims? Would not their ability to function in this way be significantly discounted? It is not clear from Saward's texts. While building on his focus on representative claims, especially their subjective nature, we tried to give a different explanation to how subjective representative claims could obtain objective meanings. We argued that, in any given community-arguably even in a "global" community-there would be values that are held as fundamentally true by all-or at least, the vast majority-of its members. Values such as justice, fairness, harmony and so on are typical ones among them. But there are also more culturally charged ones, such as the idea of "Mandate of Heaven" in ancient China. Any representative claims have to be made with reference to these values in order to obtain some level of objectivity.

However, representative claims -in whatever forms they are made-are still always subjective, in the sense that they can never be completely identified with those values. In other words, there would always be multiple ways to make representative claims on questions such as "who are the people?", "what are the people's best interests?" This applies to both what we usually call "democratic representation" and the "authoritarian" type of political representation. In democratic politics, different representatives make diverse claims simultaneously and they compete with each other in an openly and largely orderly fashion. Whereas, typical authoritarian representatives always try to make exclusive claims on, say, the people's best interests; but they still have to refer to common values in society in order to acquire objectivity for their claims. This is because there is a relative gap between authoritarian representatives and common values, they are exposed to potential critiques or challenges from society, thus, allowing a certain level of public deliberation. 
On the other hand, the "vanguard" type of representation we mentioned above goes beyond this spectrum of representation, because in there, objectivity of representative claims are entirely contained in the Marxist "historical truth" that is supposed to be imbued into the people by representatives, rather than the peoples' common values being translated by representatives into laws and policies.

As indicated, when someone in the NPC, such as Mr. Huang, stands up and challenges the Party's position, he/she would most likely point to some "high values" for which the Party could be criticized, as Huang actually did. These high values range from the most common principles of common good, to the Party's own mottos, including, "Seek Truth from Facts" (shi shi qiu shi). This would also include culturally informed ideas like conscience, historical responsibility, or even the notion of Heaven. Scholars have noticed that dissidents in China are not necessarily anti-government, as they often only want to hold the authorities accountable for their own promises (Schell, 1994). In this sense, they actually share some overarching values and principles with the authority. Even for those dissidents who are defiantly anti-establishment, they cannot be so far removed that there is nothing in terms of value that they can both lay claim to. In other words, as is visible in the Chinese case, dissidents criticized the authorities by offering an alternative representation of the people, that is, through values supposedly subscribed to by the community as a whole.

More interestingly, the Party actually does the same thing in safeguarding its own position in society. If we pay close attention to the Party's language, we will notice that, in addition to values and principles such as justice, harmony, "Seek Truth from Facts" and so on, there is an almost ubiquitous reference to the role of "history" in the CCP becoming the (only) ruling party in China. Indeed, Party leaders and theorists have often commented that "History has chosen the CCP" (Niu \& Wang, 2016; Zhang, 2017). The Communist Party is then the ultimate true bearer of history's mandate; this is because, in relation to Marxist teachings, it is the only genuine advocate of the Chinese People, and also the key to the nation's resurrection after defeat and humiliation in the hands of exploitive classes and imperialistic forces. In a sense, we could even say that, in the Party's language, the ancient Confucian ideal of the "Mandate of Heaven" has been replaced by the Mandate of History.

More importantly, in contemporary China, the Party could be and actually is restricted by these high values, as seen from the example of Mr. Huang. But there is also evidence from outside the People's Congress that is equally important. We have seen many occasions whereby the Party-led authorities have rectified some major policies or past courses, arguably on the basis of objections by society. The case of the "Re-education through Labor Act" (also known as Lao Jiao, hereinafter, abbreviated to the RLA) is perhaps, the most famous and exemplary one. Put into effect in 1957, the RLA allowed the police depart- ment to detain persons for minor crimes-such as petty theft, prostitution, etc.-without trial. Critics, including those from outside China, had long decried this act as a typical example of a human rights violation. But largely it was criticism from within the country-most notably by legal scholars and NPC representatives-that prepared the ground for its retraction (Zhou, 2012). For instance, in 2007, Professor Jiang Ping and a further 68 scholars sent a public letter to the Standing Committee of the NPC and State Council to petition for the abolition of the RLA.

Among the sources Professor Jiang and others drew on to make their case, was the state Constitution. Enacted in 1982, the Constitution clearly indicates that "No citizen may be arrested except with the approval or by decision of a people's procuratorate or by decision of a people's court." If the Constitution is the "fundamental law of the state" as it claims to be, regulations such as the RLA are basically unconstitutional. Moreover, scholars also argued that there is a requirement to "construct a harmonious society of fairness, justice, democracy, and rule of law" (Ifeng, 2010), one that the central government itself has proclaimed to guarantee. In 2013, and largely against this background, the Third Plenum of the 18th Party Congress announced that this act would be abolished. Later that year, the Standing Committee of the NPC passed a motion to formally abolish the RLA.

This case, among others, proves that it is possible for a kind of deliberation or debate on public matters to exist, despite the fact that the authority always tries to prevent alternative representative claims from surfacing in public. However, this is only possible when there exists a level of truth-composed by common valuesthat the authority has to rely on to make representative claims, but nevertheless, cannot lay exclusive claim to. The Party makes representative claims by referring to the values that the society deems true, but it is also restricted by these values. Indeed, any representative claims have to be made with reference to these values in order to acquire a sense of objectivity. But as soon as these claims are made by particular persons or parties, they are inevitably detached from those values themselves, making them inevitably subjective. As a consequence, representative claims are always subject to criticisms and challenges.

\section{Representation: Authoritarian and Democratic}

Since common values are what give representative claims objectivity and values have a lot to do with culture, it is worthwhile to discuss representative claims from a cultural historical perspective, especially since we have already mentioned the traditional cultural elements in the CCP's representative claims. But we argued that culture and its values do not only "set limits or parameters" to the type of representative claims that could plausibly be made in a given community, they also enable people in the community to propose various forms of claims. This is first and foremost clear in pre-modern China. 
In ancient China, as Duan (2014) pointed out, there was a "Heaven-Ruler-People" relationship involved in its political dynamism, in which the ruler formed a relationship with the people by referring to the "Mandate of Heaven." In the classic Confucian text, Mencius, for instance, Master Mencius stated that a ruler is a true ruler not because any other particular person-such as his father, the king-gives him the position, but only when he is ordained by Heaven (Mencius, 2009, p. 103). But how can Heaven's will be known? According to Mencius, "It is through the people that the Heaven's will is known," for "Heaven sees as my people see. Heaven hears as my people hear" (Mencius, 2009, p. 104). In this relationship, the ruler derives legitimacy from Heaven and thus become supreme, so opposing the ruler is tantamount to opposing Heaven. But in this authoritative relationship, while the "Mandate of Heaven" grants the ruler a supreme position, it also gives room for people to question his actions. Early classical Confucians even conceived the notion of the Dao, or "Way," which transcends any particular authority and to which all forms of human existence should submit (Yao, 2000, pp. 139-189). This apparent dualism of authority could indeed facilitate a certain level of deliberation on public issues, as the emperor's governance always appears to be gauged by transcendental truth, mostly by those Confucian scholars who deem their raison d'être as being the upholder of Confucian ideals (He, 2014).

To an extent, the emperor's power seems to have been both legitimized and restricted by the level of authentic values, it could perhaps be said that the emperor "represents" the people, although at that time, neither "representation" as a political concept nor the idea of sovereignty of the people existed. Eric Voegelin in his The New Science of Politics says that "articulation is the condition of representation," and that "in order to come into existence, a society must be articulate by producing a representative that will act on its behalf" (1987, p. 41). According to this idea, both King of England in ancient times and the Soviet Union government are such articulators or representatives. In our analysis, this sense of articulation could be best understood as representatives' "translation" of common values into tangible laws and policies. Moving from ancient to modern times, there is certainly no doubt that language and social political conditions are now dramatically different. The CCP is not claiming that it be sanctified by the "Mandate of Heaven". After all, it was born out of the Marxist movement with a fundamentally hostile attitude toward religious practices and symbols. Nevertheless, just as it is impossible to purge all traditional meaning from language, the Party's relationship with the People following the "representative turn" could-or shall we say, must-still be understood in a way that is not so different from what is described above.

This also sheds light on the consequences of the rejection of those traditional values and henceforth, the collapse of the "traditional" authoritarian representa- tion. In China, this happened mostly during the Cultural Revolution era, when traditional values were considered as backward and reflective of feudalistic dynastic rule. They were rejected so that people could be liberated from feudal shackles and achieve freedom. But nobody was really free because nobody was able to draw on those high values to launch criticism or minimal level of debate with regard to the authority's decisions. It is only after the end Cultural Revolution and during the Open and Reform era that people started to reclaim that relative freedom to bring up diverse representative claims. This is not to say the CCP today has stopped trying to make exclusive representative claims. But the type of representation embodied in the "Three Represents" implies that alternative representative claims from society are possible as a result of the independence of those high values.

This reflection should give us some thought on modern democratic representation as well. In modern democracies, representation is often gauged by how "truthfully" it reflects people's views and interests. We are not saying that this is wrong, but it needs much more clarification than it usually gets. As stated by Saward (2006), there is perhaps no such thing as "the truthful interests of the people" to start with. All meaningful articulations of the people's interests are constructed by representatives who are making claims. There is an undeniable and unbridgeable gap between representative claims on people's best interests and the people (or their best interests) themselves. But what is particular about democratic representation is that this gap is kept institutionally visible. That is to say, in democratic politics, it should always be legitimate and normal to propose new representative claims; and any representative claims embodied in government's laws and policies are potentially replaceable by other claims through institutional means. Whereas in authoritarian politics, the gap is kept institutionally invisible; it is definitely abnormal for people to introduce non-official representative claims on their own. It usually takes extraordinary means-such as petitions and protests - to effectively bring new claims into the political system. Traditional theories of democracy and representation tend to draw the line between democratic and authoritarian politics on the basis that, in the former, there is "representation" truthful to the people' interests, while there is no representation at all in the latter. We differ from this stance by arguing that it is not the existence of representation, but how representation is formalized and institutionalized, that distinguishes authoritarian politics from democratic politics.

\section{Conclusion}

This article delineates the transition from "vanguard" to "representation" in the CCP's articulation of its relationship with the people. We take this not as a mere play in language, but as a reflection of social reality. This is mostly seen in the true significance of the "Three 
Represents"; but it is also reflected in the Party's relationship with the People's Congress. It seems that there is a significant level of credibility or truth in the CCP's claim to represent the people, especially when compared with its other claim-being the revolutionary vanguard. But what exactly is this level of truth? Could the CCP be really understood as the representative of the Chinese people? Isn't "representation" a concept exclusively meant for democratic politics?

To answer these questions and to better explain the CCP's representative claims, we follow Pitkin and other researchers to disentangle representation and democracy. But we mainly focus on Michael Saward's idea of representative claim, as it points directly to the constructive nature of political representation without any regard to democratic institutions such as elections. Certainly, the CCP's representation of the Chinese people could be understood as a kind of construction composed by "claims," such as those embodied in the "Three Represents." But subjective representative claims need to acquire at least some objectivity so as to function in any given context. Saward believes that objectivity comes from culture; but we argue that it is common values in a given community that give objectivity to representative claims. In other words, representatives make claims by referring to common values in order to be accepted as true. But as soon as claims are made, they are inevitably detached from common values themselves.

This understanding of political representation applies to both democratic and authoritarian politics, thus, engendering the distinction between democratic and authoritarian representation. With regard to contemporary Chinese politics, the CCP's representation could be understood in terms of seemingly exclusive representative claims, which were made with reference to "high values" in China. Since those values are "common" to the society, they open way for potential criticism and public debates from society concerning the authority's decisions, however inconstant and scant they may be. This pattern of political representation is comparable to ancient authoritarian representation in the "Heaven-Ruler-People" relationship and under the idea of "Mandate of Heaven"; and it is very different from the "vanguard" kind of representation in the Cultural Revolution era. Above all, our focus on representation does not only serve to unravel one of the most important notions in contemporary Chinese politics, a notion that has barely been studied so far. It also promises a new direction in studying Chinese politics, especially considering that the field is currently dominated by the "democratic-authoritarian" dichotomy. We at once break the dichotomy by highlighting representative claims in both democratic and authoritarian politics, and redraw the line between the two on how representation is formalized and institutionalized.

This study also sheds light on modern representative democracy. Nowadays, people usually tend to believe that the main problem of democratic politics lies in the seemingly ineliminable discrepancy between represen- tatives and the People's will. This is not exactly wrong, but it is insufficient in both explaining such complexities of modern democratic politics as populism, and offering possible solutions. Our analyses showed that democracy is much more than "letting people speak their own will" and eliminating the gap between the representatives and the people. In democracies, even in a very small community with a very limited number of citizens, there has to be someone who make claims for the best interests of the people by referring to values that members of the community could identify with. We argued that the gap between the representative and the represented actually lies at the center of modern democracy. Therefore, it seems that not only can modern democracy not do away with political representation, but it is critically reliant on it in order to preserve a space for open, effective participation and public deliberation. To square the circle, if an authoritarian type of political representation is able to produce public deliberation in a limited public sphere, political representation is even more critical to democratic politics.

\section{Acknowledgments}

Professor Antoon Braeckman of the University of Leuven, Professor Yves Sintomer of Paris 8 University, Professor Haig Patapan of Griffith University (Australia) read an early version of this article. I am grateful for their valuable suggestions. I also thank the editorial team at Politics and Governance and two anonymous reviewers for their helpful comments.

\section{Conflict of Interests}

The author declares no conflict of interests.

\section{References}

Almén, O. (2013). Only the party manages cadres: Limits of Local People's Congress supervision and reform in China. Journal of Contemporary China, 22(80), 237-254.

Bo, Z. (2004). Hu Jintao and the CCP's ideology: A historical perspective. Journal of Chinese Political Science, 9(2), 27-45.

CCPS Editors. (2013). Zhong Guo Gong Chan Dang Zhang Cheng Hui Bian [Collection of the charters of the Chinese Communist Party]. Beijing: CCPS Press.

Choi, Y. (2011). The evolution of "socialism with Chinese characteristics": Its elliptical structure of socialist principles and china's realities. Pacific Focus, 26, 385-404.

Deng, X. (1994). Deng Xiaoping wen xuan [Selected works of Deng Xiaoping] (Vol. 2). Beijing: Renmin Press.

Dickson, B. J. (2003). Whom does the party represent? From "three revolutionary classes" to "Three Represents". American Asian Review, 21(1), 1-24. 
Dillon, N. (2015). Radical inequalities: China's revolutionary welfare state in comparative perspective. Cambridge, MA: Harvard University Press.

Duan, D. (2014). Reviving the past for the future? The (in)compatibility between Confucianism and democracy in contemporary China. Asian Philosophy, 24(2), 147-157.

He, B. (2014). Deliberative culture and politics: The persistence of authoritarian deliberation in china. Political Theory, 42(1), 58-81.

Huang, X. (2013). Huang Shun Xing Cai Fang Wen Da [Questions and answers with Huang Shun Xing]. Retrieved from http://www.doc88.com/p-4731603 516287.html

Ifeng. (2010). 69 Min Xue Zhe Shang Shu Hu Yu Fei Chu Lao Jiao [69 scholars' petition for the abolition of Lao Jiao]. Retrieved from http://news.ifeng. com/opinion/topic/laojiao/201004/0414_9958_ 1603357.shtml

Jia, H. (2004). The Three Represents campaign: Reform the party or indoctrinate the capitalists? Cato Journal, 24(3), 261-275.

Jiang, Z. (2013). Selected works of Jiang Zemin (Vol. 3). Beijing: Foreign Language Press.

Kamo, T., \& Takeuchi, H. (2013). Representation and Local People's Congresses in China: A case study of the Yangzhou Municipal People's Congress. Journal of Chinese Political Science, 18, 41-60.

Kuhn, R. L. (2010). How China's leaders think: The inside story of China's reform and what this means for the future. Singapore: John Wiley \& Sons.

Lenin, V. I. (1969). What is to be done? Burning questions of our movement. New York, NY: International Publishers. Li, Y. (2005). The structure and evolution of Chinese social stratification. Lanham, MD: University Press of America.

Lu, X. (2002). Dang Dai Zhong Guo She Hui Jie Ceng Yan Jiu Bao Gao [A report of contemporary chinese social stratification]. Beijing: Social Sciences Academic Press.

Manion, M. (2015). Information for autocrats: Representation in Chinese local congresses. Cambridge: Cambridge University Press.

Mencius. (2009). Mencius. New York, NY: Columbia University Press.

Niu, X., \& Wang, T. (2016). Li Shi Wei She Me Xuan Ze Zhong Guo Gong Chan Dang [Why history has chosen the Chinese Communist Party]. Changchun: Jilin Publishing Group.

Patapan, H., \& Wang, Y. (2018). The hidden ruler: Wang Huning and the making of contemporary China. Jour- nal of Contemporary China, 27(109), 47-60.

Pitkin, H. F. (1967). The concept of representation. Berkeley, CA: University of California Press.

Pitkin, H. F. (2004). Representation and democracy: An uneasy alliance. Scandinavian Political Studies, 27(3), 335-342.

Renmin Ribao. (2003). Cong Yi Wei Si Ying Qi Ye Zhu Yao Qiu Ru Dang Tan Qi [Starting from a request of a private business owner to join the Party]. Renmin Ribao. Retrieved from http://www.people.com.cn/GB/ shizheng/252/9483/10239/20030224/929072.html

Rousseau, J.-J. (2002). The social contract and the first and second discourses. New Haven, CT, and London: Yale University Press.

Saward, M. (2006). The representative claim. Contemporary Political Theory, 5, 297-318.

Saward, M. (2009). Authorization and authenticity: Representation and the unelected. The Journal of Political Philosophy, 17(1), 1-22.

Schell, O. (1994). The mandate of heaven: A new generation of entrepreneurs, dissidents, bohemians, and technocrats lays claim to China's future. New York, NY: Simon \& Schuster.

Song, X. (2005). Signs of the times: The discourse of "Three Represents" and globalisation. East Asia, 22(3), 25-40.

Truex, R. (2016). Making autocracy work: Representation and responsiveness in modern China. Cambridge: Cambridge University Press.

Voegelin, E. (1987). The new science of politics: An introduction. Chicago, IL, and London: The University of Chicago Press.

Yao, X. (2000). An introduction to Confucianism. Cambridge: Cambridge University Press.

Yi, Z. (2010). China's political system. Beijing: China International Press.

Yuan, Z. (2011). Independent candidates in China's Local People's Congress elections. Journal of Chinese Political Science, 16, 389-405.

Zhang, X. (2017). Li Shi Ru He Xuan Ze Le Zhong Guo Gong Chan Dang [How history has chosen the Chinese Communist Party]. Wuhu: Anhui Normal University Press.

Zheng, H. (2004). Zhong Guo She Hui Jie Gou Bian Hua Qu Shi Yan Jiu [A research on the transformation of the chinese social structure]. Beijing: China Renmin University Press.

Zhou, Y. (2012). Lao Jiao Zhi Du De Li Shi Yu Fei Chu Hu Sheng [The history of Lao Jiao and the calls for its abolition]. Yan Huang Chun Qiu, 12, 22-28.

\section{About the Author}

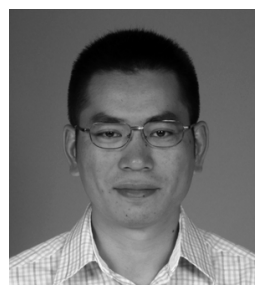

Demin Duan is an Associate Professor of Political Science at the Department of Political Science, School of Government, Peking University, China. His main research interests include democratic theories, political representation, Alexis de Tocqueville's thought and French liberalism, regime studies in a comparative perspective, etc. 